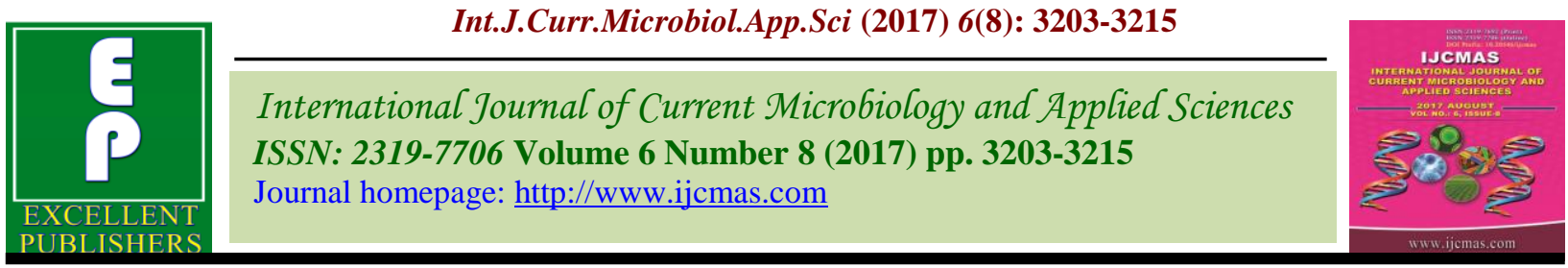

Original Research Article https://doi.org/10.20546/ijcmas.2017.608.382

\title{
Variation in Alternaria brassicae Population Causing Alternaria Blight of Rapeseed and Mustard in Assam
}

\author{
Diganggana Talukdar ${ }^{1 *}$, A. R. Baruah ${ }^{2}$, P. Debnath ${ }^{3}$ and Utpal Dey ${ }^{4}$ \\ ${ }^{1}$ Department of Plant Pathology and Microbiology, College of Horticulture, \\ CAU, Ranipool, Gangtok-737135, Sikkim, India \\ ${ }^{2}$ Department of Plant Biotechnology, ${ }^{3}$ Department of Plant Pathology, Assam Agricultural \\ University, Jorhat-785013, Assam, India \\ ${ }^{4}$ Division of Crop Production, ICAR for NEH, Umiam-793103, Meghalaya, India \\ *Corresponding author
}

A B S T R A C T

Keywords

Variability,

Alternaria blight,

Molecular

characterization,

Rapeseed and

mustard.

Article Info

Accepted:

26 June 2017

Available Online:

10 August 2017
Forty isolates of Alternaria brassicae extracted from the leaves and pods of rapeseeds and mustard collected from all the agro-climatic zones of Assam were studied for variability. The average conidial length and breadth of the isolates varied from $34.99 \mu \mathrm{m}$ to $46.36 \mu \mathrm{m}$ and $5.16 \mu \mathrm{m}$ to $9.72 \mu \mathrm{m}$; and beak length from $4.01 \mu \mathrm{mto} 18.00 \mu \mathrm{m}$. Numbers of horizontal septa and longitudinal septa ranged from 4.95 to 8.56 and 0.00 to 0.48 , respectively. Four distinct colony colours whitish gray; dark and brownish gray; gray, and greenish were identified. The isolates were compressed, slightly compressed, fluffy and slightly fluffy. Shapes of the colonies were either circular or irregular. The growth pattern was slow (0$40 \mathrm{~mm})$, medium $(41-60 \mathrm{~mm})$ and fast $(61-90 \mathrm{~mm})$. Molecular characterization revealed highest similarity $(0.435)$ between Dhemajiand Darang isolates. Maximum dissimilarity (0.00) was observed between Jorhat isolate and Dhubri isolate, and between Sivsagar and Dhubri. The dendrogrambased on similarity index generated four clusters with 7, 15, 11 and 7 isolates.

\section{Introduction}

India is said to be the paradise for oilseed crops being fourth largest oilseed producing country in the world harvesting about 25 million tons of oilseeds, and rapeseed and mustard alone contributed 32.00 per cent of total oilseed (Jha et al., 2012). In 2013-14, it produced 74.90 lakh tones with a yield of $1147 \mathrm{~kg} / \mathrm{ha}$ (ADS, 2013). Sharma and Pandey (2013) reported that despite considerable production of oilseed, a wide gap exists between the potential yield and the yield realized at the farmers' field because of incidence of Alternaria blight. Researchers have reported yield loss due to Alternaria ranging from $36.88 \%$ to $70.00 \%$ (Kolte, 1985; Saharan, 1992; Kolte, 2002; Meena et al., 2010; Bal and Kumar, 2014and Kumar et al., 2014).

Morphological, cultural and genetic variability, together or separately, within the isolates of Alternaria spp. in different regions of India as well as in the world have been reported by several authors (Meena et al., 
1972; Gherbawy, 2005; Goyal et al., 2011; Kaur et al., 2015; Saha et al., 2016; Aeneja et.al., 2014; Bind et al., 2014 and Selvamani, 2014).The importance of pathological as well as genetic level study has been highlighted for efficient management of the disease by Milgroom and Fry, 1997 and Aneja and Agnihotri, 2013.

In Assam, though large scale survey has not been carried out on the total loss caused by the Alternaria brassicae but reports from farmers' field about the disease is alarming requiring a full scale study to understand the variability of Alternaria brassicae to help develop management strategies.

\section{Materials and Methods}

\section{Collection of the samples from different agro-climatic zones of Assam}

Infected leaves and pods of rapeseed and mustard having the typical symptoms of Alternaria blight were collected from different agro-climatic zones of Assam (Table 1) and brought to the laboratory of Department of Plant Pathology, Assam Agricultural University, Jorhat within seven days of collection.

\section{Fungal isolation}

Forty isolates were isolated from the infected leaves and pods of rapeseed and mustard. The spots were first washed 3-4 times in sterilized distilled water and then surface sterilized by dipping in 4 per cent sodium hypochloride $(\mathrm{NaOCl})$ solution for 1 minute, followed by washings with sterilized water 3-4 times. Surface sterilized leaf spot pieces were then aseptically transferred to $9 \mathrm{~cm}$ Petri dishes containing Potato Dextrose Agar (PDA) and incubated at $27 \pm 1^{\circ} \mathrm{C}$ for seven days. Thereafter, growing mycelia from margin of apparently distinct colonies of the leaf spot were aseptically transferred into another Petri plate containing PDA medium, where it was grown for another 15 days at $27 \pm 1^{\circ} \mathrm{C}$ in BOD incubator. In Petri plates, the diseased portion of the sample were cut and a small portion of the infected part was transferred to a culture plate containing PDA medium and kept under constant observation for the growth. After 5 days of incubation, the organisms were subcultured for purification. Slants of each culture were prepared from purified culture and were used further for morphological, cultural and molecular characterization of the fungus.

\section{Morphological variation}

Ocular micrometer was calibrated and by use of micrometry (Meena et al., 2005), morphological variability among the 40 isolates of A. brassicae and other Alternaria spp. was studied in 2012-13 and 2013-14.

\section{Cultural variation}

Cultural characteristics of each isolates such as colony color characteristics as well as growth behavior such as morphological features and shape (circular/ irregular) was observed on PDA media and incubated in BOD incubator at $25^{\circ} \mathrm{C}$ temperature and 100 per cent relative humidity in order to detect the variation among the isolates. The colors of the cultures were taken in accordance with the help of the color chart of R.H.S (The Royal Horticultural Society, London). In this experiment, radial growth reading was taken at $15^{\text {th }}$ day of inoculation of the culture on the Petri plates.

\section{Molecular characterization}

\section{Isolation of genomic DNA}

The forty isolates of Alternaria species were grown on PDA media for 14 days at $27 \pm 1^{\circ} \mathrm{C}$. 
Fungal mat was grinded in extraction buffer or lysis buffer and then total genomic DNA was isolated. The total genomic DNA was isolated by adopting CTAB method (Doyle and Doyle, 1990). The genomic DNA isolated from the isolates was checked for quality and quantity with sprectrophotometer and agarose gel electrophoresis.

\section{RAPD analysis}

Total 10 RAPD PCR primers were used starting from series OPD1, OPD2 to OPD 10 from Operon Technologies, USA which successfully amplified the DNAs and are depicted in Table 2.

The polymerase chain reaction (PCR) was carried out in Gene Amp 9700 thermal cycler PCR machine. The PCR master mix was prepared with $1 \mathrm{X}$ Taqpolymerase buffer, 1.8 $\mathrm{mM} \mathrm{MgCl}_{2}, 0.4$ mMdNTPs, $0.4 \mathrm{pM}$ primers and $1.5 \mathrm{U}$ of Taqpolymerase. Thereafter, 20 $\mu l$ of master mix was added with $5 \mu$ DNA in PCR tubes. Each PCR amplification reaction was preceded by an initial denaturation at $94^{\circ} \mathrm{C}$ for $4 \mathrm{~min}$ followed by forty PCR amplification cycles by denaturation at $94^{\circ} \mathrm{C}$ for $1 \mathrm{~min}$, annealing at $37^{\circ} \mathrm{C}$ for $1 \mathrm{~min}$ and extension at $72^{\circ} \mathrm{C}$ for $1 \mathrm{~min}$ and then followed by final extension at $72^{\circ} \mathrm{C}$ for $10 \mathrm{~min}$. The amplified products were separated by electrophoresis in $1.5 \%$ (w/v) agarose (Genei, Bangalore) gel with $1 \mathrm{X}$ TBE buffer, stained with ethidium bromide $(0.5 \mu \mathrm{g} / \mathrm{ml})$ at $90 \mathrm{~V}$ for 3.0 to $3.5 \mathrm{~h}$ and photographed using gel documentation system (Bio Rad, USA, model). The sizes of the amplification product were estimated using $1 \mathrm{~kb}$ ladder (Fermentas Life Sciences, Canada). Each PCR was repeated thrice and only sharp, reproducible amplicons were considered for fingerprint analysis of the isolates. Gel images were scored manually and recorded on the present/absent matrix data. These data were used as an input file for calculating similarity index using software NTSYS PC 2.02i (Rolf, 1997). A dendrogram was derived from the distance matrix by UPGMA (Sneath and Sokal, 1973).

\section{Results and Discussion}

\section{Morphometric variation}

Morphometric variation of forty isolates collected from six agro climatic zones depicted in Table 3 and Plate 1 showed high level of variability in spore morphology in respect to conidial length, width and number of both transverse and longitudinal septa.

In the total sample, average conidial length and breadth varied from $34.99 \mu \mathrm{m}$ (Is 7_Nal) to $46.36 \mu \mathrm{m}$ (Is 31_Siv) and $5.16 \mu \mathrm{m}$ (Is 18_Dhe and Is 28_Jor) to $9.72 \mu \mathrm{m}$ (Is 24_Nag) respectively. In case of beak length, the average length varied from $4.01 \mu \mathrm{m}$ (Is 9_Nal) to $18.00 \mu \mathrm{m}$ (Is 7_Nal). Horizontal septa showed higher degree of variation compared to longitudinal septa. Number of horizontal septa and longitudinal septa ranged from 4.95 (Is 7_Nal) to 8.56 (Is 14_Kok) and 0.00 (Is 18_Dhe) to 0.48 (Is 5_Dhu, Is 12_Bar, Is 17_Lak, Is 31_Siv) respectively.

Aneja et al., 2014 reported high variation in spore size of Alternaria brassicae isolates with 37.7 to $257.6 \mu \mathrm{m}$ with beak sizes of 27.8 to $120.2 \mu \mathrm{m}$. Similar findings were reported by Selvamani (2014), who collected forty isolates from different cauliflower, rapeseed and mustard growing locations in India and characterized for morphological variations.

All the isolates showed high level of variability in spore morphology in respect to conidial length, width and number of septa. The present findings were also in accordance with the findings of Goyal et al., (2011), who reported morphometric variation of thirteen Alternaria brassicae isolates of rapeseed and 
mustard and found that average conidial length ranged from $31.2 \mu \mathrm{m}$ to $51.8 \mu \mathrm{m}$, average conidial breadth ranged from $6.7 \mu \mathrm{m}$ to $9.6 \mu \mathrm{m}$, average beak length ranged from $8.2 \mu \mathrm{m}$ to $19.2 \mu \mathrm{m}$, transverse septa ranged between 4.8 to 7.2 numbers while longitudinal septa ranged from 0.0 to 0.4 numbers. A number of research workers (Saha et al., 2016; Kaur et al., 2015; Meena et al., 2010 and Verma and Saharan, 1994) recorded morphological variations in Alternaria spp.

\section{Cultural variation}

Data presented in Table 4 and Plate 2, showed high level of variability among forty isolates collected from six Agro climatic zones. Variability was found in vitro in respect to mycelia growth rate, growth pattern or morphological features, colony shape and color.

The isolates showed varied colors in the PDA (Potato dextrose media). The colors were whitish gray, gray, brownish gray, dark gray and greenish.

Based on the findings, the total samples have been grouped into four sections accordingly. Isolates that showed whitish gray are grouped under Group I (Isolates Is 1_Kam, Is 7_Nal, Is 8_Nal, Is 15_Lak, Is 24_Nag, Is 33_Gol, Is 34_Gol, Is 38_NC, Is 39_Kar); dark gray and brownish gray are under Group II (Isolates Is 4_Dhu, Is 5_Dhu, Is 9_Nal, Is 10_Bar, Is 11_Bar, Is 12_Bar, Is 21_Dar); gray under group III (Isolates Is 2_Kam, Is 3_Kam, Is 6_Nal, Is 13_Kok, Is 14_Kok, Is 16_Lak, Is 17_Lak, Is 18_Dhe, Is 19_Dhe, Is 20_Dar, Is 22_Nag, Is 23_Nag, Is 25_Mor, Is 26_Mor, Is 27_Jor, Is 28_Jor, Is 30_Jor, Is 31_Siv, Is 32_Siv, Is 35_Dib, Is 36_Tin, Is 37_Kar) and greenish under group IV (Isolates Is 29_Jor and Is 40_Cac). Twenty three isolates showed gray color, nine showed whitish gray, four showed dark gray, two showed brown and two showed greenish color.

The isolates showed four types of morphological features i.e., compressed, slightly compressed, fluffy and slightly fluffy and most of the isolates showed fluffy type of morphological features. Thirty two showed fluffy, five compressed, two slightly compressed and one slightly fluffy. Twenty six isolates produced circular shaped colonies while fourteen colonies produced irregular shaped colonies.

In case of radial growth which was taken on $15^{\text {th }}$ day of inoculation, the diameter ranged from 32.00 to $88.57 \mathrm{~mm}$. Highest growth was on Is 21_Dar $(88.57 \mathrm{~mm})$, then comes Is 31_Siv with $88.25 \mathrm{~mm}$ in diameter, lowest radial growth was in isolate Is 10_Bar $(32.00 \mathrm{~mm})$, second lowest was in Is 30_Jor $(32.05 \mathrm{~mm})$.The growth pattern was categorized into three types, viz., slow (0$40 \mathrm{~mm}$ ), medium (41-60mm) and fast (61$90 \mathrm{~mm}$ ). In slow growth five isolates (Is 4_Dhu, is 10_Bar, Is 11_Bar, Is 29_Jor and Is 30_Jor), medium three isolates (Is 12_Bar, Is 34_Gol and Is 35_Dib) and in fast growth remaining thirty two isolates were found.

The results were found to be very similar with that of Selvamani (2014), who characterized forty isolates of Alternaria brassicae from different cauliflower, cabbage and mustard growing in locations of India and found high variability in vitro in respect to mycelia growth, growth pattern and colour. Jha et al., (2013) reported colony colors of $A$. brassicaeas rather pale olive or gray or dark gray in color and having fluffy or compressed topography.

Meena et al., (2012) found regular to irregular colony shape; cottony white, dark green to light brown mycelial growth among twenty three isolates of $A$. brassicae and further 
grouped the colonies into four based on colony colors, viz., Group 1 (white to pale gray), Group 2 (dark olive gray to iron gray colonies), Group 3 (gray to olive gray colonies) and Group 4 (lettuce green to olive green color). Kaur et al., 2015 found the colonies brown, while and olevaceous green with smooth or wavy margins and thick velvety to sparse growth. Aneja et al., 2014 and Saha et al., 2016 also reported.

Table.1 Alternaria brassicae isolates collected from different pockets of six Agro-climatic Zones of Assam

\begin{tabular}{|c|c|c|c|c|}
\hline Districts & Pockets & Isolates name & Latitude & Longitude \\
\hline \multicolumn{5}{|c|}{ Lower Brahmaputra Valley Zone (LBVZ) } \\
\hline \multirow{3}{*}{ Kamrup } & Kahikuchi & Is 1_Kam & $26.3588^{\circ} \mathrm{N}$ & $91.1329^{\circ} \mathrm{E}$ \\
\hline & Boko & Is 2_Kam & $25.9778^{\circ} \mathrm{N}$ & $91.2356^{\circ} \mathrm{E}$ \\
\hline & Hajo & Is 3_Kam & $26.2519^{\circ} \mathrm{N}$ & $91.5257^{\circ} \mathrm{E}$ \\
\hline \multirow{2}{*}{ Dhubri } & Bilasipara & Is 4_Dhu & $26.2300^{\circ} \mathrm{N}$ & $90.2300^{\circ} \mathrm{E}$ \\
\hline & Mancachar & Is 5_Dhu & $25.5300^{\circ} \mathrm{N}$ & $89.8700^{\circ} \mathrm{E}$ \\
\hline \multirow{4}{*}{ Nalbari } & Belshor & Is 6_Nal & $26.3981^{\circ} \mathrm{N}$ & $91.3638^{\circ} \mathrm{E}$ \\
\hline & Goreshwar & Is 7_Nal & $26.5400^{\circ} \mathrm{N}$ & $91.7300^{\circ} \mathrm{E}$ \\
\hline & Kamarkuchi & Is 8_Nal & $26.0856^{\circ} \mathrm{N}$ & $91.8537^{\circ} \mathrm{E}$ \\
\hline & Tihu & Is 9_Nal & $26.4749^{\circ} \mathrm{N}$ & $91.2689^{\circ} \mathrm{E}$ \\
\hline \multirow[t]{3}{*}{ Barpeta } & Pathshala & Is 10_Bar & $26.4994^{\circ} \mathrm{N}$ & $91.1793^{\circ} \mathrm{E}$ \\
\hline & Bahari & Is 11_Bar & $26.2546^{\circ} \mathrm{N}$ & $91.1379^{\circ} \mathrm{E}$ \\
\hline & Baradi & Is 12_Bar & $26.3274^{\circ} \mathrm{N}$ & $91.0507^{\circ} \mathrm{E}$ \\
\hline \multirow[t]{2}{*}{ Kokrajar } & Gossaigaon & Is 13_Kok & $26.4197^{\circ} \mathrm{N}$ & $89.9842^{\circ} \mathrm{E}$ \\
\hline & Salakati & Is 14_Kok & $26.4933^{\circ} \mathrm{N}$ & $90.3625^{\circ} \mathrm{E}$ \\
\hline \multicolumn{5}{|c|}{ North Blank Plain Zone (NBPZ) } \\
\hline \multirow[t]{3}{*}{ Lakhimpur } & Ghalimora & Is 15_Lak & $26.4400^{\circ} \mathrm{N}$ & $92.3456^{\circ} \mathrm{E}$ \\
\hline & Dhokuwakhana & Is 16_Lak & $27.2300^{\circ} \mathrm{N}$ & $94.1000^{\circ} \mathrm{E}$ \\
\hline & Narayanpur & Is 17_Lak & $26.9964^{\circ} \mathrm{N}$ & $93.8969^{\circ} \mathrm{E}$ \\
\hline \multirow[t]{2}{*}{ Dhemaji } & Gogamukh & Is 18_Dhe & $27.4303^{\circ} \mathrm{N}$ & $94.3102^{\circ} \mathrm{E}$ \\
\hline & Bordoloni & Is 19_Dhe & $26.8022^{\circ} \mathrm{N}$ & $93.5635^{\circ} \mathrm{E}$ \\
\hline \multirow[t]{2}{*}{ Darrang } & Machkhowa & Is 20_Dar & $26.1779^{\circ} \mathrm{N}$ & $91.7374^{\circ} \mathrm{E}$ \\
\hline & Norowathan & Is 21_Dar & $27.2861^{\circ} \mathrm{N}$ & $94.4449^{\circ} \mathrm{E}$ \\
\hline \multicolumn{5}{|c|}{ Central BrahmaputraValley zone (CBVZ) } \\
\hline \multirow[t]{3}{*}{ Nagaon } & Shillongoni & Is 22_Nag & $26.3503^{\circ} \mathrm{N}$ & $92.6922^{\circ} \mathrm{E}$ \\
\hline & Raha & Is 23_Nag & $26.2327^{\circ} \mathrm{N}$ & $92.5278^{\circ} \mathrm{E}$ \\
\hline & Mikirgaon & Is 24_Nag & $26.1407^{\circ} \mathrm{N}$ & $92.6933^{\circ} \mathrm{E}$ \\
\hline \multirow[t]{2}{*}{ Morigaon } & Mayong & Is 25_Mor & $26.2589^{\circ} \mathrm{N}$ & $92.0408^{\circ} \mathrm{E}$ \\
\hline & Banmurigaon & Is 26_Mor & $26.4800^{\circ} \mathrm{N}$ & $90.5600^{\circ} \mathrm{E}$ \\
\hline \multicolumn{5}{|c|}{ Upper Brahmaputra Valley zone (UBVZ) } \\
\hline \multirow[t]{4}{*}{ Jorhat } & Titabor & Is 27_Jor & $26.6000^{\circ} \mathrm{N}$ & $94.2000^{\circ} \mathrm{E}$ \\
\hline & Teok & Is 28_Jor & $26.8130^{\circ} \mathrm{N}$ & $94.4065^{\circ} \mathrm{E}$ \\
\hline & AAU, ICR farm & Is 29_Jor & $26.4400^{\circ} \mathrm{N}$ & $94.0000^{\circ} \mathrm{E}$ \\
\hline & Majuli & Is 30_Jor & $26.9500^{\circ} \mathrm{N}$ & $94.1667^{\circ} \mathrm{E}$ \\
\hline \multirow[t]{2}{*}{ Sivsagar } & Dimow & Is 31_Siv & $27.1268^{\circ} \mathrm{N}$ & $94.7400^{\circ} \mathrm{E}$ \\
\hline & Amguri & Is 32_Siv & $26.5800^{\circ} \mathrm{N}$ & $94.5230^{\circ} \mathrm{E}$ \\
\hline \multirow[t]{2}{*}{ Golaghat } & Dergaon & Is 33_Gol & $26.7000^{\circ} \mathrm{N}$ & $93.9700^{\circ} \mathrm{E}$ \\
\hline & Borpothar & Is 34_Gol & $27.4728^{\circ} \mathrm{N}$ & $94.9119^{\circ} \mathrm{E}$ \\
\hline Dibrugarh & Sarupathar & Is 35_Dib & $26.1946^{\circ} \mathrm{N}$ & $93.8629^{\circ} \mathrm{E}$ \\
\hline Tinsukia & Doom Dooma & Is 36_Tin & $27.5700^{\circ} \mathrm{N}$ & $95.5700^{\circ} \mathrm{E}$ \\
\hline \multicolumn{5}{|l|}{ Hill Zone (HZ) } \\
\hline KarbiAnglong & Badarpur & Is 37_Kar & $24.9000^{\circ} \mathrm{N}$ & $92.6000^{\circ} \mathrm{E}$ \\
\hline North Cachar Hill & Haflong & Is 38_NC & $25.1800^{\circ} \mathrm{N}$ & $93.0300^{\circ} \mathrm{E}$ \\
\hline \multicolumn{5}{|c|}{ Barrak Valley Zone (BVZ) } \\
\hline Karimgang & Diphu & Is 39_Kar & $25.8300^{\circ} \mathrm{N}$ & $25.8300^{\circ} \mathrm{N}$ \\
\hline Cachar & Silchar & Is 40_Cac & $24.8200^{\circ} \mathrm{N}$ & $24.8200^{\circ} \mathrm{N}$ \\
\hline
\end{tabular}


Table. 2 Primer code and sequence of fragments amplified by the RAPD marker

\begin{tabular}{|c|c|}
\hline Primer & Sequence $5^{\prime}$ to $3^{\prime}$ \\
\hline OPD1 & ACCGCGAAGG \\
\hline OPD2 & GGACCCAACC \\
\hline OPD 3 & GTCGCCGTCA \\
\hline OPD 4 & TCTGGTGAGG \\
\hline OPD 5 & TGAGCGGACA \\
\hline OPD 6 & ACCTGAACGG \\
\hline OPD 7 & TTGGCACGGG \\
\hline OPD 8 & GTGTGTCCCA \\
\hline OPD 9 & CTCTGGAGAC \\
\hline OPD 10 & GGTCTACACC \\
\hline
\end{tabular}

Table.3 Morphological variation of Alternaria brassicae isolates from different agro-climatic Zones of Assam

\begin{tabular}{|c|c|c|c|c|c|c|c|c|c|c|}
\hline \multirow[t]{3}{*}{ Isolate } & \multicolumn{2}{|c|}{$\begin{array}{c}\text { Conidial length } \\
(\mu \mathrm{m})\end{array}$} & \multicolumn{2}{|c|}{$\begin{array}{c}\text { Conidial breadth } \\
(\mu \mathrm{m})\end{array}$} & \multicolumn{2}{|c|}{$\begin{array}{c}\text { Beak length } \\
(\mu \mathrm{m})\end{array}$} & \multicolumn{4}{|c|}{$\begin{array}{l}\text { Septation } \\
(\mu \mathrm{m})\end{array}$} \\
\hline & \multirow[t]{2}{*}{ Average } & \multirow[t]{2}{*}{ Range } & \multirow[t]{2}{*}{ Average } & \multirow[t]{2}{*}{ Range } & \multirow[t]{2}{*}{ Average } & \multirow[t]{2}{*}{ Range } & \multicolumn{2}{|l|}{ Transverse } & \multicolumn{2}{|c|}{ Longitudinal } \\
\hline & & & & & & & Average & Range & Average & Range \\
\hline \multicolumn{11}{|l|}{ LBVZ } \\
\hline Is 1_Kam & 35.62 & $35.00-38.50$ & 6.63 & $6.00-7.50$ & 10.76 & $9.50-15.50$ & 5.05 & $4-6$ & 0.42 & $0-2$ \\
\hline Is 2_Kam & 38.30 & $34.30-40.40$ & 6.19 & $5.50-6.00$ & 11.00 & $9.00-18.00$ & 6.01 & $6-7$ & 0.38 & $0-2$ \\
\hline Is 3_Kam & 38.22 & $35.00-40.80$ & 6.25 & $6.00-7.20$ & 10.50 & $8.00-15.50$ & 5.01 & $5-6$ & 0.24 & $0-1$ \\
\hline Is 4_Dhu & 41.18 & $30.00-50.00$ & 8.73 & $7.20-12.00$ & 13.52 & $9.50-20.00$ & 6.93 & $5-7$ & 0.41 & $0-2$ \\
\hline Is 5_Dhu & 40.90 & $30.00-45.00$ & 8.93 & $7.00-11.00$ & 8.44 & $4.80-12.00$ & 6.97 & $5-7$ & 0.48 & $0-4$ \\
\hline Is 6_Nal & 36.18 & $30.00-36.00$ & 7.22 & $6.00-6.50$ & 8.28 & $4.80-12.00$ & 5.11 & $5-6$ & 0.26 & $0-2$ \\
\hline Is 7_Nal & 34.99 & $30.00-35.00$ & 5.85 & $6.00-6.50$ & 18.00 & $9.00-20.00$ & 4.95 & $4-5$ & 0.41 & $0-2$ \\
\hline Is 8_Nal & 37.75 & $30.00-38.00$ & 6.18 & $5.00-6.00$ & 8.59 & $4.85-11.55$ & 5.01 & $4-6$ & 0.00 & $0-0$ \\
\hline Is 9_Nal & 37.60 & $30.00-40.00$ & 6.22 & $5.00-6.00$ & 8.55 & $4.55-12.00$ & 5.12 & $4-5$ & 0.16 & $0-1$ \\
\hline Is 10_Bar & 40.33 & $38.00-45.00$ & 7.85 & $10.00-12.00$ & 4.01 & $2.01-7.09$ & 7.38 & $6-8$ & 0.21 & $0-3$ \\
\hline Is 11_Bar & 36.36 & $34.00-37.50$ & 5.33 & $5.00-7.54$ & 10.66 & $9.53-15.45$ & 5.29 & $4-6$ & 0.45 & $0-1$ \\
\hline Is 12_Bar & 37.86 & $34.35-40.43$ & 6.06 & $5.54-6.06$ & 11.66 & $9.05-18.05$ & 5.89 & $4-5$ & 0.48 & $0-2$ \\
\hline Is 13_Kok & 38.18 & $35.05-45.80$ & 6.35 & $6.50-7.20$ & 11.60 & $8.00-15.60$ & 5.40 & $6-7$ & 0.28 & $0-1$ \\
\hline Is 14_Kok & 45.18 & $34.00-50.00$ & 9.69 & $7.40-11.07$ & 13.93 & $10.54-24.00$ & 8.56 & $7-8$ & 0.44 & $0-2$ \\
\hline \multicolumn{11}{|l|}{ NBPZ } \\
\hline Is 15_Lak & 41.13 & $34.00-46.00$ & 9.48 & $7.55-11.30$ & 13.70 & $9.05-24.00$ & 8.48 & $7-9$ & 0.02 & $0-0$ \\
\hline Is 16_Lak & 36.66 & $30.00-36.00$ & 6.00 & $6.00-4.50$ & 8.70 & $4.90-12.50$ & 5.93 & $5-7$ & 0.41 & $0-1$ \\
\hline Is 17_Lak & 45.16 & $30.00-36.00$ & 6.56 & $6.55-6.505$ & 8.80 & $4.75-12.40$ & 6.13 & $5-7$ & 0.48 & $0-1$ \\
\hline Is 18_Dhe & 36.74 & $30.00-38.00$ & 5.16 & $5.06-6.06$ & 8.54 & $4.84-11.00$ & 5.03 & $4-5$ & 0.00 & $0-0$ \\
\hline Is19_Dhe & 37.33 & $32.05-40.05$ & 6.51 & $5.05-6.05$ & 4.02 & $2.00-5.05$ & 5.88 & $5-6$ & 0.20 & $0-1$ \\
\hline Is 20_Dar & 40.00 & $38.35-45.20$ & 8.18 & $10.00-12.00$ & 6.05 & $3.00-9.05$ & 7.42 & $6-7$ & 0.21 & $0-3$ \\
\hline Is 21_Dar & 38.36 & $35.35-38.50$ & 6.33 & $6.00-7.50$ & 10.86 & $9.50-15.50$ & 5.91 & $5-6$ & 0.40 & $0-2$ \\
\hline \multicolumn{11}{|l|}{ CBVZ } \\
\hline Is 22_Nag & 36.14 & $35.30-41.40$ & 6.29 & $5.50-6.00$ & 11.14 & $9.00-18.00$ & 6.05 & $6-7$ & 0.40 & $0-2$ \\
\hline Is 23_Nag & 40.04 & $38.00-43.80$ & 6.32 & $6.00-7.20$ & 10.66 & $8.00-15.50$ & 5.67 & $5-6$ & 0.21 & $0-1$ \\
\hline Is 24_Nag & 40.67 & $30.00-45.00$ & 9.72 & $7.20-12.00$ & 13.66 & $9.50-20.00$ & 6.92 & $5-7$ & 0.40 & $0-2$ \\
\hline Is 25_Mor & 40.11 & $30.55-46.00$ & 9.66 & $7.00-11.00$ & 13.51 & $9.00-20.00$ & 6.60 & $5-7$ & 0.45 & $0-3$ \\
\hline Is 26_Mor & 37.44 & $37.00-36.00$ & 6.11 & $6.00-6.50$ & 8.24 & $4.86-12.50$ & 5.48 & $5-6$ & 0.45 & $0-2$ \\
\hline \multicolumn{11}{|l|}{ UBVZ } \\
\hline Is 27_Jor & 35.66 & $30.00-35.00$ & 6.07 & $6.00-6.50$ & 8.00 & $4.80-12.00$ & 5.59 & $5-6$ & 0.41 & $0-2$ \\
\hline Is 28_Jor & 35.85 & $30.00-38.00$ & 5.16 & $5.00-6.00$ & 8.00 & $4.80-11.00$ & 5.28 & $5-6$ & 0.45 & $0-3$ \\
\hline Is 29_Jor & 38.00 & $30.00-40.00$ & 6.33 & $5.00-6.00$ & 8.00 & $4.00-10.00$ & 5.18 & $5-6$ & 0.06 & $0-1$ \\
\hline Is 30_Jor & 42.53 & $40.00-45.00$ & 8.15 & $10.00-12.00$ & 8.96 & $4.00-11.05$ & 6.04 & $6-7$ & 0.21 & $0-3$ \\
\hline Is 31_Siv & 46.36 & $38.00-47.08$ & 6.37 & $6.00-7.50$ & 10.75 & $9.70-15.50$ & 5.23 & $5-6$ & 0.48 & $0-2$ \\
\hline Is 32_Siv & 38.33 & $34.30-40.40$ & 6.08 & $5.50-6.00$ & 11.00 & $9.00-18.00$ & 6.16 & $6-7$ & 0.47 & $0-2$ \\
\hline Is 33_Gol & 37.55 & $35.00-40.80$ & 6.25 & $6.00-7.20$ & 10.55 & $8.00-15.50$ & 5.49 & $4-6$ & 0.23 & $0-1$ \\
\hline Is 34_Gol & 40.71 & $30.00-50.00$ & 8.55 & $7.20-12.00$ & 17.62 & $9.50-20.00$ & 7.58 & $5-8$ & 0.41 & $0-2$ \\
\hline Is 35_Dib & 38.58 & $30.00-45.00$ & 8.15 & $7.00-11.00$ & 13.29 & $9.00-20.00$ & 7.05 & $5-8$ & 0.13 & $0-0$ \\
\hline Is 36_Tin & 35.55 & $30.00-36.00$ & 6.04 & $6.00-6.50$ & 8.23 & $4.80-12.00$ & 5.55 & $4-6$ & 0.40 & $0-2$ \\
\hline \multicolumn{11}{|l|}{$\mathbf{H Z}$} \\
\hline Is 37_Kar & 35.32 & $30.00-35.00$ & 6.32 & $6.05-6.50$ & 13.02 & $11.98-14.00$ & 5.89 & $4-6$ & 0.34 & $0-2$ \\
\hline Is 38_NC & 36.29 & $30.00-38.00$ & 5.18 & $5.00-6.00$ & 8.00 & $4.80-11.00$ & 4.83 & $4-5$ & 0.05 & $0-0$ \\
\hline \multicolumn{11}{|l|}{ BVZ } \\
\hline Is 39_Kar & 38.04 & $30.00-40.00$ & 6.74 & $5.00-6.00$ & 10.01 & $6.00-12.05$ & 5.44 & $4-6$ & 0.20 & $0-3$ \\
\hline Is 40_Cac & 45.55 & $38.00-46.00$ & 8.52 & $11.00-12.00$ & 7.01 & $5.05-8.09$ & 5.53 & $4-6$ & 0.38 & $0-1$ \\
\hline CD (5\%) & 1.448 & & 0.980 & & 0.849 & & 1.55 & & 1.55 & \\
\hline
\end{tabular}


Table.4 Cultural variation of Alternaria brassicae isolates from different agro-climatic Zones of Assam

\begin{tabular}{|c|c|c|c|c|c|}
\hline \multirow[t]{2}{*}{ Isolate } & \multicolumn{5}{|c|}{ Cultural characteristics } \\
\hline & $\begin{array}{l}\text { Colour on PDA } \\
\text { plates }\end{array}$ & $\begin{array}{l}\text { Morphological } \\
\text { features }\end{array}$ & $\begin{array}{l}\text { Shape (Circular/ } \\
\text { irregular) }\end{array}$ & $\begin{array}{c}\text { Radial Growth on } 15^{\text {th }} \text { day of inoculation } \\
(\mathrm{mm})\end{array}$ & Groups \\
\hline \multicolumn{6}{|c|}{$\mathrm{C}_{1}$} \\
\hline Is 1_Kam & Whitish gray & Compressed & Circular & 76.05 & I \\
\hline Is 2_Kam & Gray & Fluffy & Circular & 75.95 & III \\
\hline Is 3_Kam & Gray & Fluffy & Circular & 62.23 & III \\
\hline Is 4_Dhu & Dark gray & Compressed & Irregular & 37.90 & II \\
\hline Is 5_Dhu & Dark gray & Compressed & Circular & 75.05 & II \\
\hline Is 6_Nal & Gray & Slightly compressed & Circular & 72.00 & III \\
\hline Is 7_Nal & Whitish gray & Fluffy & Circular & 80.03 & $\mathrm{I}$ \\
\hline Is $8 \_\mathrm{Nal}$ & Whitish gray & Fluffy & Circular & 81.00 & I \\
\hline Is 9_Nal & Dark Gray & Fluffy & Circular & 80.00 & II \\
\hline Is 10_Bar & Brownish gray & Fluffy & Irregular & 32.00 & II \\
\hline Is 11_Bar & Brownish gray & Fluffy & Irregular & 34.76 & II \\
\hline Is 12_Bar & Gray & Fluffy & Irregular & 42.00 & II \\
\hline Is $13 \_$Kok & Gray & Fluffy & Circular & 76.06 & III \\
\hline Is 14_Kok & Gray & Fluffy & Irregular & 72.95 & III \\
\hline \multicolumn{6}{|l|}{ NBPZ } \\
\hline Is 15_Lak & Whitish gray & Fluffy & Circular & 79.09 & I \\
\hline Is 16_Lak & Gray & Fluffy & Irregular & 65.05 & III \\
\hline Is 17_Lak & Gray & Fluffy & Circular & 80.32 & III \\
\hline Is 18_Dhe & Gray & Fluffy & Circular & 81.44 & III \\
\hline Is19_Dhe & Gray & Fluffy & Irregular & 72.07 & III \\
\hline Is 20_Dar & Gray & Fluffy & Irregular & 62.06 & III \\
\hline Is 21_Dar & Dark gray & Slightly compressed & Circular & 88.57 & II \\
\hline \multicolumn{6}{|l|}{ CBVZ } \\
\hline Is 22_Nag & Gray & Fluffy & Irregular & 77.54 & III \\
\hline Is 23_Nag & Gray & Fluffy & Circular & 87.77 & III \\
\hline Is 24_Nag & Whitish gray & Fluffy & Circular & 75.55 & I \\
\hline Is 25_Mor & Gray & Slightly fluffy & Circular & 87.79 & III \\
\hline Is 26_Mor & Gray & Fluffy & Circular & 72.00 & III \\
\hline \multicolumn{6}{|l|}{ UPVZ } \\
\hline Is 27_Jor & Gray & Compressed & Circular & 67.05 & III \\
\hline Is 28_Jor & Gray & Fluffy & Circular & 66.09 & III \\
\hline Is 29_Jor & Greenish & Fluffy & Circular & 35.05 & IV \\
\hline Is 30_Jor & Gray & Fluffy & Irregular & 32.05 & III \\
\hline Is 31_Siv & Gray & Fluffy & Circular & 88.25 & III \\
\hline Is 32_Siv & Gray & Fluffy & Irregular & 80.75 & III \\
\hline Is 33_Gol & Whitish gray & Fluffy & Circular & 80.77 & I \\
\hline Is 34_Gol & Whitish gray & Fluffy & Irregular & 55.59 & I \\
\hline Is 35_Dib & Gray & Fluffy & Irregular & 57.44 & III \\
\hline \multicolumn{6}{|l|}{$\mathbf{H Z}$} \\
\hline Is 36_Tin & Gray & Compressed & Circular & 88.05 & III \\
\hline Is 37_Kar & Gray & Fluffy & Circular & 81.16 & III \\
\hline Is 38_NC & Whitish Gray & Fluffy & Irregular & 65.55 & $\mathrm{I}$ \\
\hline \multicolumn{6}{|l|}{ BVZ } \\
\hline Is 39_Kar & Whitish Gray & Fluffy & Circular & 79.22 & $\mathrm{I}$ \\
\hline Is 40_Cac & Greenish & Fluffy & Circular & 72.55 & IV \\
\hline
\end{tabular}

Table.5 Primer-wise score of PCR amplification products scored in the 40 isolates of Alternaria brassiace

\begin{tabular}{|l|c|c|}
\hline \multirow{2}{*}{ Primer } & \multicolumn{2}{|c|}{ Number of PCR amplification fragments generated } \\
\cline { 2 - 3 } & Monomorphic bands & \multicolumn{2}{|c|}{ Polymorphic bands } \\
\hline OPD1 & 1 & 5 \\
\hline OPD2 & 0 & 5 \\
\hline OPD4 & 2 & 5 \\
\hline OPD5 & 1 & 6 \\
\hline OPD6 & 0 & \\
\hline OPD7 & 0 & 7 \\
\hline OPD8 & 0 & 8 \\
\hline OPD9 & 2 & 5 \\
\hline OPD10 & 1 & \\
\hline
\end{tabular}



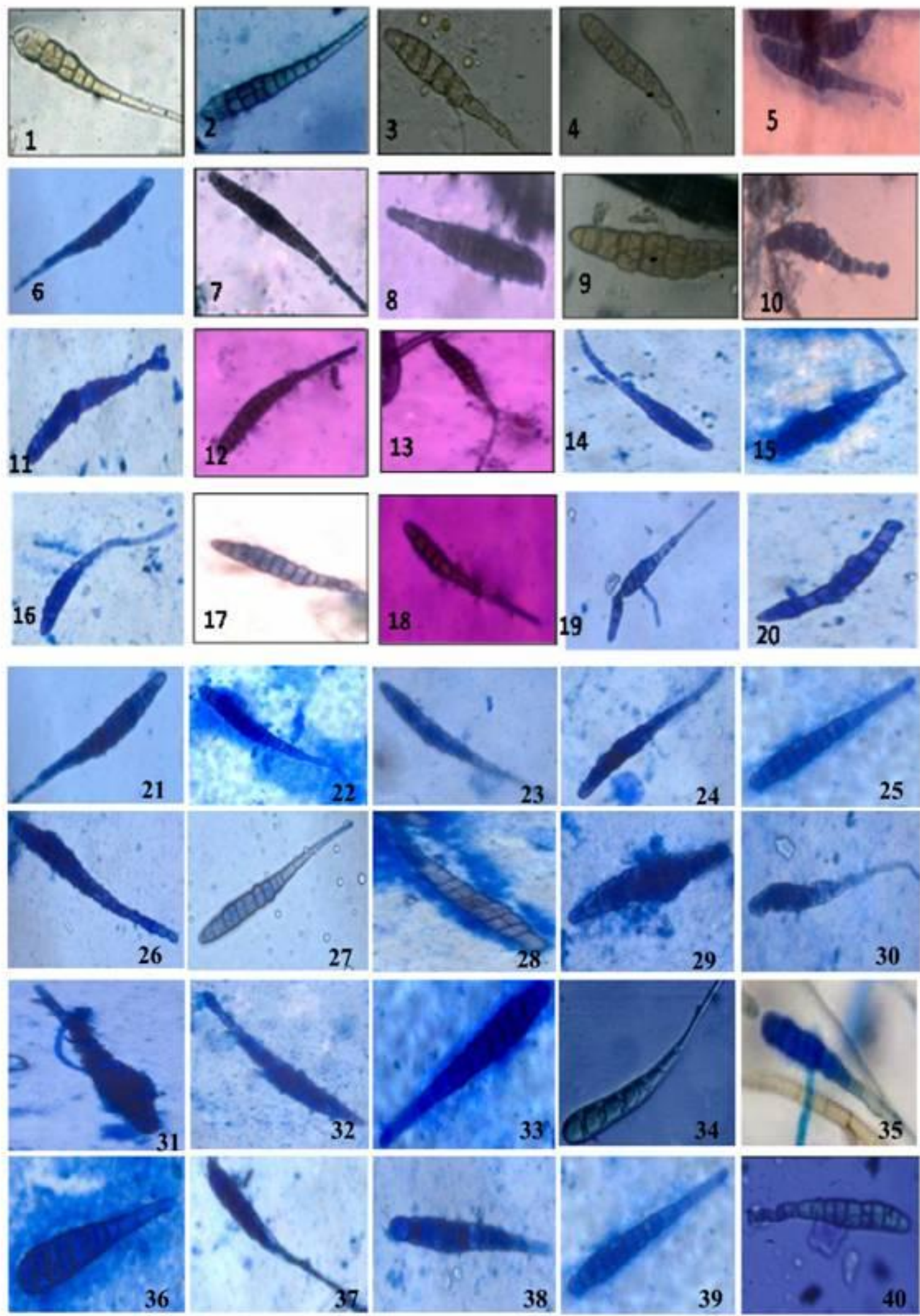

Plate 1: Conidial structures of Alternaria brassicae (1-40) under Phase Contrast microscope (Maginification 40X) 

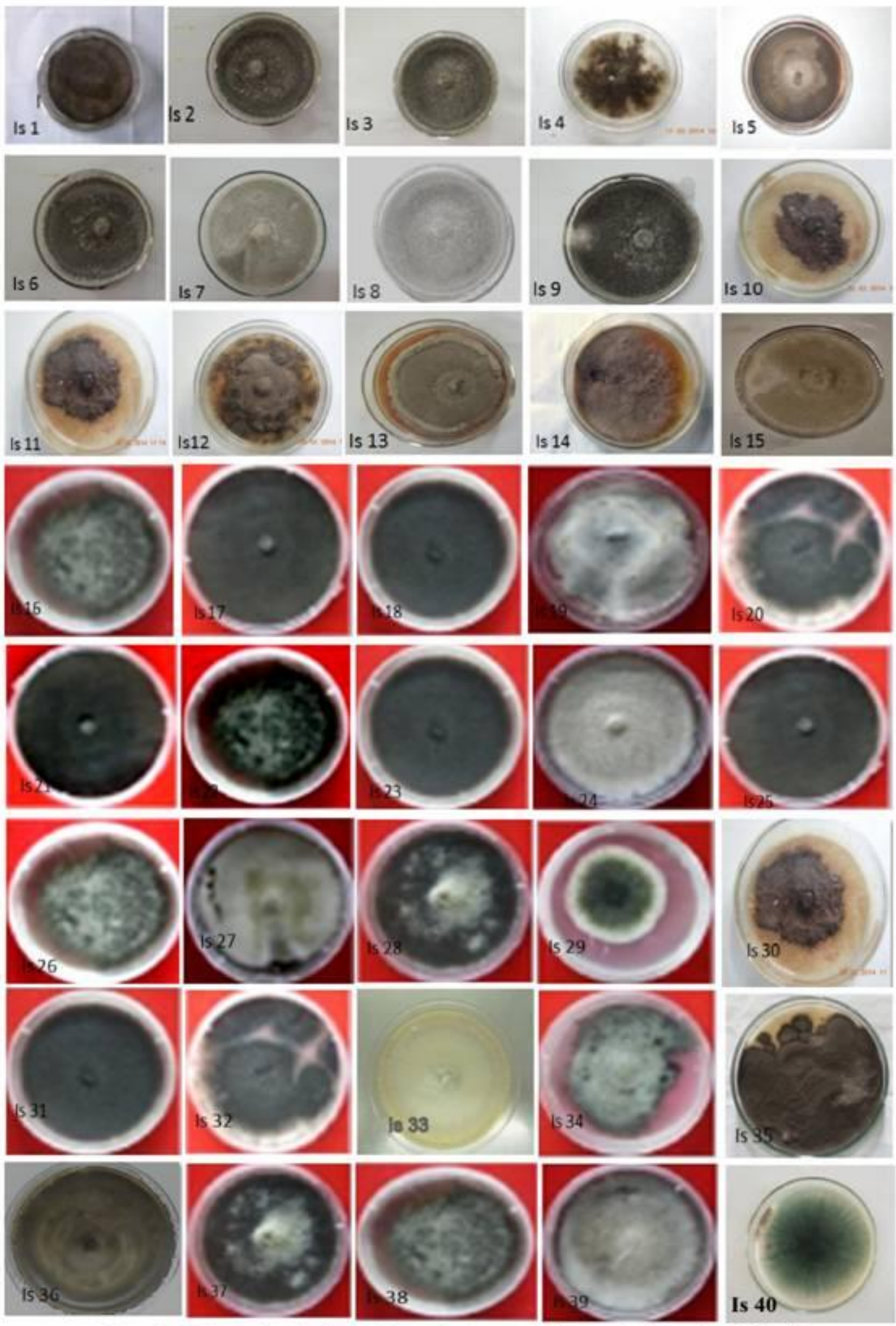

Plate 2: Cultural variation of forty isolates of Alternaria brassicae (Is1-40) 


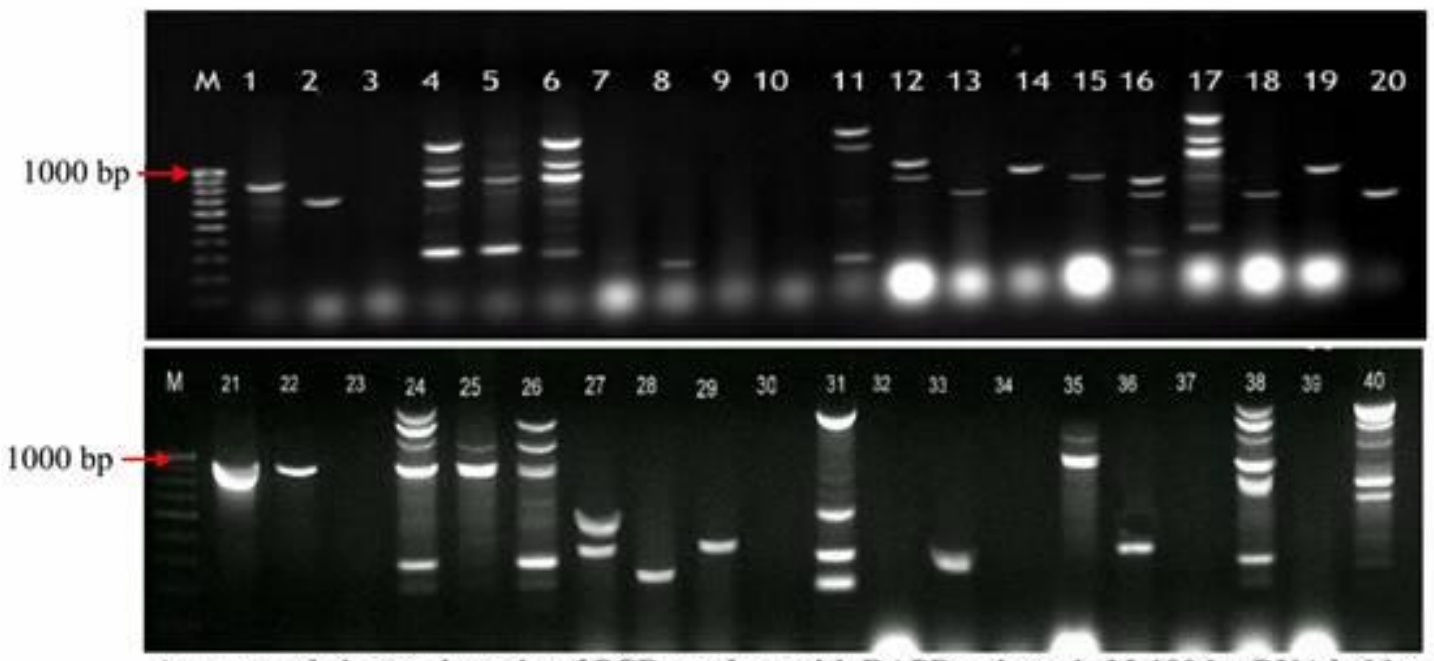

Agarose gel electrophoresis of PCR product with RAPD primer 1; M-100 bp DNA ladder
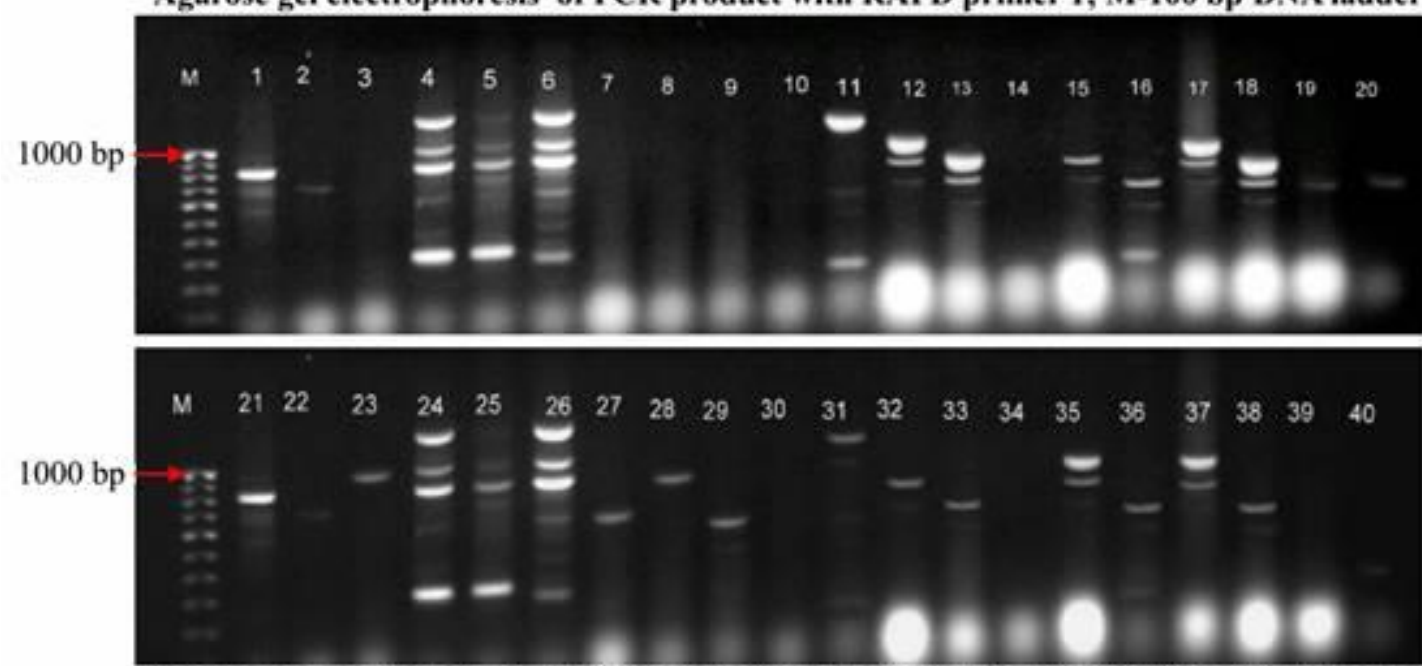

Agarose gel electrophoresis of PCR product with RAPD primer 6; M-100 bp DNA ladder
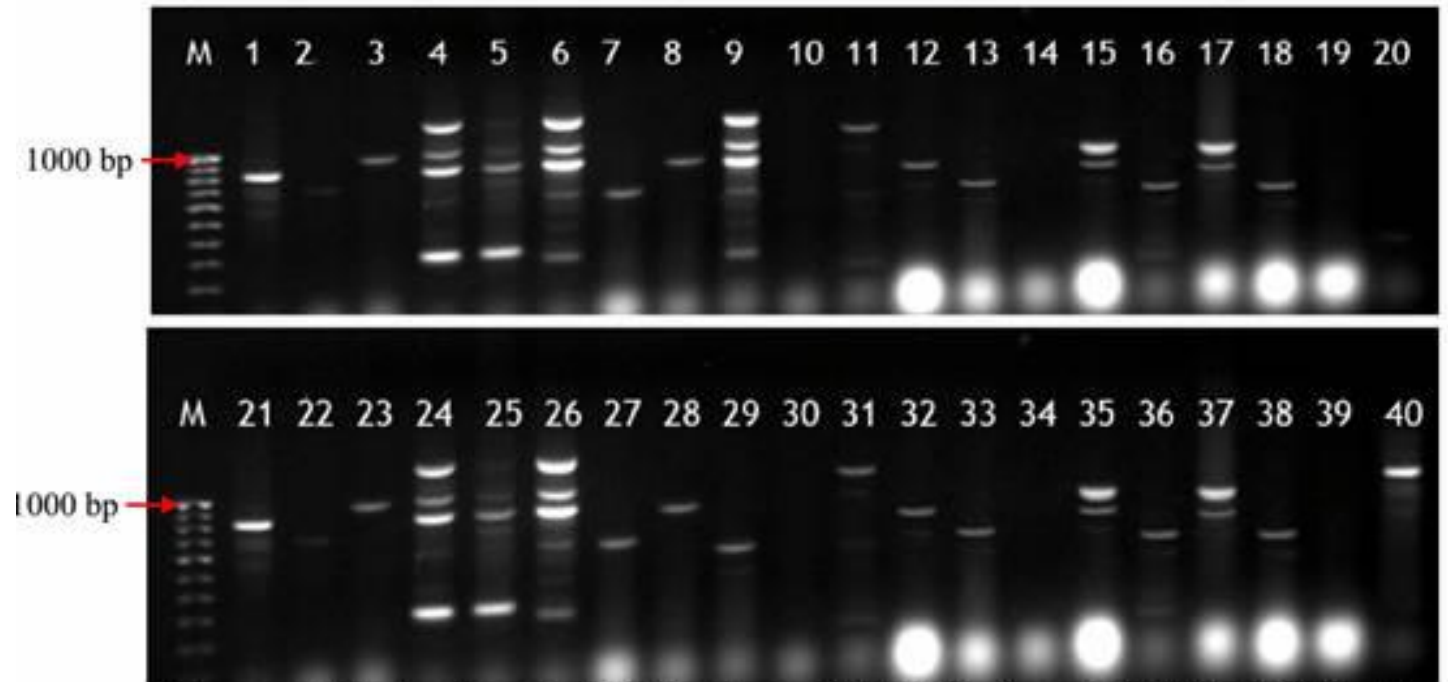

Agarose gel electrophoresis of PCR product with RAPD primer 9; M-100 bb DNA ladder

Plate 3. Molecular characterization 


\section{Molecular characterization}

The authenticity of variations among the various isolates of $A$. brassicae can be obtained only after confirming their genetic variations. It is considered as powerful tools to analyze genetic relationships and diversity. Forty isolates of A. brassicae of rapeseed and mustard which were subjected for molecular characterization using ten RAPD markers (OPD1 to OPD 10) generated good number of polymorphic bands and the polymorphism was clearly distributed as shown in Table 5. Good quality genetic profiling was obtained. A total of 71 RAPD loci were amplified from different isolates. Most of the PCR products were in size range of $650-1000 \mathrm{bp}$. Out of the 71 bands scored $62(87.32 \%)$ were found to be polymorphic and $9(12.67 \%)$ were found to be monomorphic in nature. The frequencies of polymorphic bands obtained varied from primer to primer. Wide genetic variation between isolates of the species was evident from the high number of polymorphic marker and unique bands, even though small number of isolates available.

Jaccard's coefficient of similarity among the isolates was calculated. Maximum similarity was found in between Dhemaji isolate (Is 18_Dhe) and Darang isolate (Is 20_Dar) with coefficient of similarity (0.435). Next to this, 0.400 coefficient of similarity was found between Darang (Is 21_Dar) and Dhemaji (Is 19_Dhe) and also between Darang (Is 21_Dar) and Darang (Is 20_Dar). All the above four isolates were extracted from samples collected from single agro-climatic zone-NBPZ. The isolates, Is 18_Dhe and Is 20_Dar are gray and fluffy and shared similarities in morphological parameters.

Maximum dissimilarity was observed between Jorhat isolate (Is29_Jor) and Dhubri isolate (Is 4_Dhu) and between Sivsagar (Is 32_Siv) and Dhubri (Is 5_Dhu) i.e 0.00. By comparing the amplification profile with 30 bands, it has been found that there was no sharing of common band between each pairs of the isolates (Is 29_Jor, Is 4_Dhu and Is 32_Siv and Is 5_Dhu). However, Jaccard's Coefficient of similarity takes into account sharing of the amplified band that may be the reason for getting 0.00 per cent similarity. Use of more numbers of markers might have resolved the problem of 0.00 per cent similarity. Next to zero per cent, least genetic similarity (0.038) was found between Jorhat (Is 30_Jor) and Kamrup (Is 1_Kam) and also between Jorhat (Is 30_Jor) and Barpeta (Is 11_Bar) isolates. The Is29_Jor isolate was greenish, fluffy and circular in shape while the Dhubri isolate (Is 4_Dhu) was dark gray, compressed and irregular shaped. In terms of morphological character, average conidial length, breadth, beak length and septation were much less in Is29 Jor isolate compared to Is 4_Dhu. Similar trend was observed between Dhubriisolate (Is 5_Dhu) and Sivsagarisolate (Is 32_Siv).

The dendrogram (Fig. 1) generated with the similarity data was grouped into four clusters. Cluster I consist of 7 isolates (Is 1_Kam, Is 7_Nal, Is 8_Nal, Is 4_Dhu, Is 14_Kok, Is 33_Gol and Is 40_Cac). Cluster 1 isolates were mostly concentrated in LBVZ with whitish gray and fluffy growth. Cluster II isolates (Is 2_Kam, Is 5_Dhu, Is 30_Jor, Is 31_Siv, Is 6_Nal, Is 38_NC, Is 24_Nag, Is 34_Gol, Is 39_Kar, Is 9_Nal, Is 11_Bar, Is 12_Bar, Is 13_Kok, Is 16_Lak and Is 25_Mor) spread over all the geographical locations with maximum concentration in LBVZ and were mostly gray, fluffy and circular shaped. Cluster III consists of 11 isolates (Is 10 Bar, Is 26_Mor, Is 27_Jor, Is 28_Jor, Is 17_Lak, Is 18_Dhe, Is 20_Dar, Is 19_Dhe, Is 21_Dar, Is 35_Dib and Is 36_Tin) and were concentrated in NBPZ and UBVZ. They exhibited mostly gray, fluffy and circular character. The Cluster IV consists of 
7 isolates (Is 15_Lak, Is 32_Siv, Is 37_Kar, Is 22_Nag, Is 23_Nag, Is 3_Kam and Is 29_Jor) spread over almost all the zones and were fluffy. The information reveals genetic and cultural and morphological variation in the isolates across the state.

The present findings are supportive of Aneja et al., 2014 who reported high level of genetic diversity (57\% to $78 \%$ ) amongst $A$. brassicae isolates as revealed by RAPD banding profile. The analysis of similarity matrix data also revealed high level of diversity $(82.83 \%)$ among all the isolates from different regions of India (Anejaet al., 2014).

The study confirms Cultural, morphological and genetical variations among the Alternaria brassicae isolates across different agroclimatic zones of Assam. The isolates with different genetical characterization did not express similar morphological and cultural characteristics. The results provide useful information for breeding programs, epidemiological studies as well as improved disease management strategies.

\section{References}

Agricultural Statistics Dept. (2014). First Advance Estimates of Production of Oilseeds \& Other Commercial Crops for 2013-14

Aneja, J.K. and Agnihotri, A. (2013).Alternaria Blight of Oilseed Brassicas: Epidemiology and Disease Control Strategies with Special Reference to Use of Biotechnological Approaches for attaining Host Resistance. J. Oilseed Brassica 4(1):1-10.

Aneja, J.K., Agarwal, A. and Agnihotri, A. (2014). Inter and Intra specific diversity in Alternaria Species infecting oilseed Brassicas in India. J. Oilseed Brassica5(2):102-117.

Bal, R.S. and Kumar, A. (2014). Studies on the epidemiology of White rust and
Alternaria leaf blight and their effects on yield of Indian mustard. Afr. J. Agric. Res.9:302-306.

Bind, D., Singh, D. and Daivedi, V.K. (2014). Genetic variability and character association in Indian Mustard [Brassica junceae (L) CZERNS \& COSS]. Agric. Sci. Digest., 34(3):183-188.

Doyle, J.J. and Doyle, J.L. (1990). A rapid total DNA preparation procedure for fresh plant tissue. Focus. 12:13-15.

Gherbawy, Y. (2005). Genetic variation among isolates of Alternaria spp. from selected Egyptian crops. Archives of Phytopath\& Plant Protec. 38(2):77-89.

Goyal, P., Chahar, M., Mathur, A.P., Kumar, A. and Chattopadhyay, C. (2011). Morphological and cultural variation in different oilseed Brassica isolates of Alternaria brassicae from different geographical regions of India. Indian $J$. Agric. Sci. 81(11): 1052-1058.

Gulati, V.P. and Phansakar, S.J. (1994). Oilseed and Edible oil Economy of India. First edition, Vikash Publishing House Pvt. Ltd., New Delhi- 110014. pp: 1-44.

Jha, G.K., Pal, S., Mathur, V.C., Bisaria, G., Anbukkani, P., Burman, R.R. and Dubey, S.K. (2012).Edible Oilseeds Supply and Demand Scenario in India. Division of Agricultural Economics, Indian Agricultural Research Institute, New Delhi - 110012. pp:1-37.

Jha, P., Kumar, M., Meena, P.D. and Lal, H.C. (2013). Dynamics and management of Alternaria blight disease of Indian mustard (Brassica juncea) in relation to weather parameters. J. Oilseed Brassica4(2): 66-74.

Kaur, S., Singh, G. and Banga, S.S. (2015). Documenting variation in Alternaria brassicae isolates based on conidial morphology, fungicidal sensitivity and molecular profile. Plant Protection: Diseases : 87-89.

Kolte, S.J.(1985). Disease management strategies for rapeseed and mustard crops in India. Agric Rev6:81-88. 
Kolte, S.J. (2002). Diseases and their management in oilseed crops, new paradigm in oilseeds and oils: research and development needs (eds. ManglaRai; Harvir Singh and D.M. Hegde.). Indian Society of Oilseeds Research. Hyderabad, India. Pp.244-252.

Kumar, D., Maurya, N., Bharti, Y.K., Kumar, A., Kumar, K., Srivastava, K., Chand, G., Kushwaha, C., Singh, S.K., Mishra, R.K. and Kumar, A. (2014).Alternaria blight of oilseed brassicas -A comprehensive review. Afr. J. Microbiol. Res.8:28162829.

Meena, P.D., Awasthi, R.P., Chattopadhyay, C., Kolte, S.J. and Kumar, A. (2010). Alternaria blight: a chronic diseae in rapeseed mustard. J oilseed Brassica1:111.

Meena, P.D., Rani, A., Meena, R.,Sharma, P., Gupta, R. and Chowdappa, P. (2012). Aggressiveness, diversity and distribution of Alternaria brassicae isolates infecting oilseed Brassica in India. African $J$ Microbiol Res. 6:5249-5258.

Meena, P.D., Chattopadhyay, C., Kumar, V.R., Meena, R.L., and Rana, U.S. (2005). Spore behaviour in atmosphere and trends in variability of Alternaria brassicae population in India. J. Mycol. Plant Pathol.35:511.

Milgroom, M.G. and Fry, W.E. (1997). Contribution of population genetics to plant disease epidemiology and management. Adv Bot Res. 24:1-30.
Rolf, F. (1997). NTSYS - pc: numerical taxonomy and multivariate analysis system version2.0 Exeter Software. Setauket, New York: Applied Biostatistics Inc.

Saha, S., Garg, R., Venkataravanappa, V., Mishra, P.K., Rai, A.B. and Singh, R.P. (2016). Molecular and cultural characterization of Alternaria brassicae infecting cauliflower in Uttar Pradesh. India. Proc. Natl. Acad. Sci., India, Sect. B Biol. Sci. 86(2):485-495.

Saharan, G.S. (1992). Management of rapeseed and mustard diseases In: Advances in Oilseed Research, Science Publication, India, 1:152-533.

Selvamani, R. (2014). Epidemiology and diversity of Alternariabrassiace (Berk) Sacc.the causal agent of black leaf spot in crucifers. Division of Plant Pathology, IARI, New Delhi, 110012.

Sharma, S.N. and Pandey, R.N. (2013). Survival, epidemiology and management of Alternaria blight of cumin in Gujrat. Bioinfolet.10(2B): 639-642.

Sharma, T.R. and Tiwari, J.P. (1995). Detection of genetic variation in Alternaria brassicae by RAPD fingerprints. J. Plant Biochem Biotechnol.4:105-107.

Sharma, T.R. and Tiwari, J.P. (1998). RAPD analysis of three Alternaria spp. pathogenic to crucifers. Mycol. Res.120: 807-814.

Sneath, P.H.A. and Sokal, R.R. (1973).Numerical Taxonomy. W. H. Freeman \& Co., San Francisco. p.573.

\section{How to cite this article:}

Diganggana Talukdar, A.R. Baruah, P. Debnath and Utpal Dey. 2017. Variation in Alternaria brassicae Population Causing Alternaria Blight of Rapeseed and Mustard in Assam. Int.J.Curr.Microbiol.App.Sci. 6(8): 3203-3215. doi: https://doi.org/10.20546/ijcmas.2017.608.382 